\title{
ACOUSTIC STUDIES OF COPPER SOAP-UREA COMPLEXES DERIVED FROM GROUNDNUT AND SESAME OILS
}

\author{
A. K. Sharma ${ }^{1}$, M. Saxena ${ }^{2}$, R. Sharma ${ }^{1}$ \\ ${ }^{1}$ Department of Chemistry, S. P. C. Govt. College, Ajmer-305001, Rajasthan, India \\ ${ }^{2}$ Department of Chemistry, S. D. Govt. College, Beawar-305901, Rajasthan, India \\ e-mail: sharmaarun423@gmail.com
}

(Received May 30, 2017; in final form - December 19, 2017)

\begin{abstract}
Ultrasonic velocities and densities have been measured in ternary mixtures containing copper soap-urea complexes derived from groundnut and sesame oils in a $20 \%$ and a $40 \%$ methanolbenzene mixture. From these values, the specific acoustic impedance $Z$, adiabatic compressibility $\beta$, intermolecular free length $L_{\mathrm{f}}$, apparent molar compressibility $\phi_{k}$, molar sound velocity $R$, primary solvation number $S_{n}$ have been calculated. The results have been analyzed in terms of Masson's equation. The results have been explained on the basis of intermolecular interactions, and the effect of the polarity of the solvent molecules and the concentration of solute molecules were accessed on various acoustic parameters. Our results also suggest that the behavior of soap complex in benzene dominated environment and methanol dominated environment is quite different as they occupy different positions in palisade layers of soap complexes agglomerations.

Key words: copper soap-urea complex, groundnut oil, sesame oil, acoustic parameters, intermolecular interactions, CMC.
\end{abstract}

PACS number(s): $62.60 .+\mathrm{v}$

\section{INTRODUCTION}

Surface-active agents are vital components in biological systems and play an important role in many industrial processes. Because of their ability to lower interfacial tension, surfactants are used as emulsifiers, detergents, dispersing agents, foaming agents, wetting agents [1,2]. Although the use of surfactants in preservation of wood, water proofing and repellency, protection of crops, stabilization of nylon threads, lubrication etc. are relatively newer applications [3,4]. Copper soaps have a tendency of complex formation with the compounds containing donors like $\mathrm{N}, \mathrm{O}, \mathrm{Br}$ and $\mathrm{S}$, etc. $[5,6]$. It is well known that compounds containing $\mathrm{N}$ and $\mathrm{S}$ atoms play a significant role in biological activities and have sufficient industrial and analytical applications [7]. The nature of micelles has been clarified by research techniques such as NMR, ESR, neutron scattering. A variety of methods have been used to determine the CMC with or without additives in surfactants solutions [8]. The Grüneisen parameter and the internal pressure obtained from ultrasonic velocity and density data play a significant role in understanding internal structure, clustering phenomenon and the quasi-crystalline nature of a binary mixture [9]. Ultrasonic measurements have also been used to determine the solvation number in aqueous media [10].

\section{METHODOLOGY}

All the chemicals used were of LR/AR grade. The oils were procured directly from the seeds of groundnut, and sesame. The fatty acid composition of the oils was confirmed by sending their methyl esters to RSIC, CDRI, Lucknow, U. P. India mentioned in Table 1.

\begin{tabular}{|c|c|c|c|c|c|c|}
\hline Name of oil & \multicolumn{6}{|c|}{$\%$ Fatty Acids } \\
\cline { 2 - 7 } & $16: 0$ & $18: 0$ & $18: 1$ & $18: 2$ & $18: 3$ & Other Acids \\
\hline Groundnut Oil & 10 & 4 & 61 & 18 & - & $C_{20} C_{40} \% 7$ \\
\hline Sesame Oil & 8 & 4 & 45 & 41 & - & - \\
\hline
\end{tabular}

Table 1. Fatty acid composition of the oils used for copper soap synthesis.

Copper soaps were prepared by refluxing the oils with a $2 \mathrm{~N} \mathrm{KOH}$ solution and alcohol for about $3 \mathrm{~h}$ (direct metathesis). The excess of $\mathrm{KOH}$ was neutralized using $1 \mathrm{~N} \mathrm{HCl}$. A saturated solution of copper sulphate was added to it. The copper soap obtained was filtered, washed with warm water followed by alcohol, dried at $50^{\circ} \mathrm{C}$ and recrystallized with hot benzene. Copper soapurea complexes were prepared by taking copper soap and urea in molar ratio (1:1). 0.005 moles of ligand (urea) was dissolved in 2-3 ml of ethyl alcohol and 0.005 moles of $\mathrm{Cu}$ (II) soap derived from various edible oils were dissolved in 10-15 $\mathrm{ml}$ of benzene and solution of urea was added to it. The above reaction mixture was then heated for 1.5 h. The separated solid complex was filtered, washed with hot water and alcohol and dried in a vacuum over fused calcium chloride. The dried sample was purified and recrystallized from hot benzene. These complexes are solid and green and are soluble in a benzene and methanolbenzene solvent mixture but are insoluble in water; all the complexes are quite stable. The formation of copper soap and their urea complexes was confirmed by using IR, UV, NMR technique [11,12]. The details of these complexes are summarized in Table 2.

\begin{tabular}{|c|c|c|c|c|}
\hline Compound & Colour & M.P. & $\%$ Metal & Mol.Wt. \\
\hline CGU & Dark Green & 85 & 9.31 & 716 \\
\hline CSeU & Dark Green & 90 & 9.16 & 706 \\
\hline
\end{tabular}

Table 2. Analytical and physical data of $\mathrm{Cu}$ (II) soap-urea complexes. 
The ultrasonic velocity was determined with the help of a single crystal ultrasonic interferometer model M-82 (Mittal Enterprises, New Delhi) working at a fixed frequency of $2 \mathrm{MHz}$. Water was maintained at $30 \pm 1^{\circ} \mathrm{C}$ and controlled up to $\pm 1^{\circ} \mathrm{C}$ by a thermostat that was passed through the jacket of the cell before the measurement was actually made. The measured velocities have an uncertainty of $0.5 \mathrm{~ms}^{-1}$. Further the operative part of the measurement involves the slow movement of a micrometer till the anode current meter shows a maximum. A number of maxima readings of anode current are passed on and their number $n$ is counted.

\section{ACOUSTIC PARAMETERS}

The total distance $d$ thus moved by the micrometer gives the value of the wavelength $\lambda$ with the help of the following relation:

$$
d=n \times \lambda / 2 .
$$

Once the wavelength is known, the velocity $u$ in the liquid can be calculated with the help of the following relation:

$$
u=\lambda \times f .
$$

The specific acoustic impedance $Z$, adiabatic compressibility $\beta$, intermolecular free length $L_{\mathrm{f}}$, apparent molar compressibility $\phi_{k}$, molar sound velocity $R$, and primary solvation number $S_{n}$ have been calculated by the following formulas:

$$
\begin{gathered}
z=u \times \rho, \\
\beta=1 /\left(u^{2} \rho\right), \\
L_{\mathrm{f}}=k \sqrt{ } \beta, \\
\phi_{k}=\left[1000\left(\beta \rho_{0}-\beta_{0} \rho\right) / C \rho_{0}\right]+\beta_{0} M / \rho_{0}, \\
R=M u^{1 / 3} / \rho, \\
M=X_{1} M_{1}+X_{2} M_{2}+X_{3} M_{3}, \\
S_{n}=\left(n_{0} / n\right)\left[1-V \beta / n_{0} V_{0} \beta_{0}\right],
\end{gathered}
$$

where $\beta_{0}, \beta, \rho_{0}, \rho, n_{0}, n, V_{0}, V$ are adiabatic compressibility, density, numbers of moles and molar volume of solvent and solute respectively; $k, c$ and $u$ are the temperature dependent Jacobson's constant having value $6.31 \times 10^{4}$, concentration in $\mathrm{g} \mathrm{mol} \mathrm{l}^{-1}$, and ultrasonic velocity, respectively. The expression for the molar volume of the solvent $V_{0}$ and soap solution $V$ may be written as under:

$$
\begin{gathered}
V=X_{1} M_{1}+X_{2} M_{2}+X_{3} M_{3} / \rho, \\
V_{0}=X_{1} M_{1}+X_{2} M_{2}+X_{3} M_{3} / \rho_{0} .
\end{gathered}
$$

In equations (7), (9) and (10), $M$ represents the molecular weight and $X$, the mole fraction of the component. Here the subscript 1,2 and 3 refer to soap complexes, methanol and benzene respectively.

\section{RESULTS AND DISCUSSION}

\section{A. Copper soap-urea complex derived from groundnut and sesame oils in a $\mathbf{2 0} \%$ methanol-benzene mixture}

\section{Acoustic Parameters}

After a perusal of the observed data, it may be mentioned that the acoustic parameters and equations related to ultrasonic investigations are the same as have been enumerated for the above soaps. The values of ultrasonic velocity and allied parameters for these complexes in the methanol-benzene mixture are given in Tables 3-4. A perusal of the data suggests that the values of $u, Z, \phi_{k}$, $R$ and $S_{n}$ increas with increasing the complex concentration whereas $\beta$ and $L_{\mathrm{f}}$ decrease with the increase in the concentration. Acoustic impedance $Z$ has a greater significance as a characteristic property of the medium than either density or ultrasonic velocity individually. The values of $\mathrm{Z}$ follow the order:

$$
\mathrm{CSeU}>\mathrm{CGU},
$$

which indicates that the lyophobic interaction between complex and solvent molecules is higher in $\mathrm{CSeU}$ than in CGU. It may be suggested that as $\mathrm{C}=\mathrm{O}$ and $\mathrm{NH}_{2}$ groups of urea are capable of making intermolecular hydrogen bonding with other CSeU molecules; their interactions strengthens contribution is the highest. For both the complexes, the values of $\beta$ and $L_{\mathrm{f}}$ decrease with increasing the complex concentration, which indicates that there are significant interactions between complex and solvent molecules. It is interesting to point out that the values of the parameters $u, Z, \beta$ and $L_{\mathrm{f}}$ with respect to chain length of the complex follows the order [13]:

$$
\begin{aligned}
& u: \mathrm{CSeU}>\mathrm{CGU}, \\
& Z: \mathrm{CSeU}>\mathrm{CGU}, \\
& \beta: \mathrm{CSeU}<\mathrm{CGU}, \\
& L_{\mathrm{f}}: \mathrm{CSeU}<\mathrm{CGU} .
\end{aligned}
$$

For both the complexes the solvation number $S_{n}$ increases with the increases in the complex concentration signifying the aggregation of solvent molecules around the solute moiety [14]. Negative values of the solvation number indicate that the solutions are more compressible than the solvent. Many authors report a negative solvation number [15]. These results indicate that a strong solutesolvent interaction takes place in the solution. In general, one can consider two types of interactions between the component molecules such as physical and chemical interactions which are arising from dispersion forces or weak dipole--dipole interactions making a positive contribution and the chemical or specific interactions due to the charge transfer, hydrogen bond formation and other complex forming interaction results in negative values [16]. 


\begin{tabular}{|c|c|c|c|c|c|c|c|c|}
\hline$c, \mathrm{~mol} \mathrm{l}^{-1}$ & $\rho, \mathrm{g} \mathrm{dm}^{-3}$ & $u, \mathrm{~m} \mathrm{~s}^{-1}$ & $Z \times 10^{-5}$ & $\beta \times 10^{11}$ & $L_{\mathrm{f}} \times 10^{10}$ & $-\phi_{k} \times 10^{8}$ & $R \times 10^{-2}$ & $S_{n} \times 10^{-3}$ \\
\hline 0.0003 & 0.9550 & 1492 & 1.4254 & 4.7005 & 1.3575 & 3306.3 & 34.344 & -64.387 \\
\hline 0.0004 & 0.9559 & 1509 & 1.4429 & 4.5915 & 1.3417 & 2764.5 & 34.443 & -46.156 \\
\hline 0.0006 & 0.9573 & 1526 & 1.4615 & 4.4816 & 1.3255 & 2038.6 & 34.529 & -29.416 \\
\hline 0.0008 & 0.9587 & 1570 & 1.5056 & 4.2292 & 1.2876 & 1853.8 & 34.810 & -19.801 \\
\hline 0.0010 & 0.9595 & 1600 & 1.5352 & 4.0711 & 1.2633 & 1644.9 & 35.003 & -14.715 \\
\hline 0.0011 & 0.9568 & 1626 & 1.5558 & 3.9530 & 1.2449 & 1587.7 & 35.294 & -12.699 \\
\hline 0.0012 & 0.9573 & 1659 & 1.5889 & 3.7920 & 1.2193 & 1591.7 & 35.520 & -10.689 \\
\hline 0.0013 & 0.9577 & 1673 & 1.6028 & 3.7277 & 1.2089 & 1520.2 & 35.607 & -9.513 \\
\hline 0.0014 & 0.9582 & 1709 & 1.6379 & 3.5715 & 1.1833 & 1525.0 & 35.843 & -8.043 \\
\hline 0.0016 & 0.9588 & 1739 & 1.6675 & 3.4483 & 1.1627 & 1413.0 & 36.032 & -6.491 \\
\hline 0.0018 & 0.9595 & 1777 & 1.7058 & 3.2976 & 1.1370 & 1341.6 & 36.276 & -5.176 \\
\hline 0.0020 & 0.9600 & 1818 & 1.7455 & 3.1510 & 1.1115 & 1281.7 & 36.536 & -4.141 \\
\hline
\end{tabular}

Table 3. The ultrasonic velocity and other acoustic parameters of the copper groundnut soap-urea complex in a $20 \%$ methanol benzene mixture $\mathrm{CGU}_{20}$.

\begin{tabular}{|c|c|c|c|c|c|c|c|c|}
\hline$c, \mathrm{~mol} \mathrm{l}^{-1}$ & $\rho, \mathrm{g} \mathrm{dm}^{-3}$ & $\mathrm{u}, \mathrm{m} \mathrm{s}^{-1}$ & $Z \times 10^{-5}$ & $\beta \times 10^{11}$ & $L_{\mathrm{f}} \times 10^{10}$ & $-\phi_{k} \times 10^{8}$ & $R \times 10^{-2}$ & $S_{n} \times 10^{-3}$ \\
\hline 0.0003 & 0.9552 & 1540 & 1.4712 & 4.4130 & 1.3153 & 4269.2 & 34.698 & -57.430 \\
\hline 0.0004 & 0.9560 & 1542 & 1.4742 & 4.3991 & 1.3132 & 3247.4 & 34.685 & -42.770 \\
\hline 0.0006 & 0.9572 & 1545 & 1.4794 & 4.3733 & 1.3094 & 2218.5 & 34.674 & -28.155 \\
\hline 0.0008 & 0.9581 & 1551 & 1.4866 & 4.3355 & 1.3037 & 1716.8 & 34.691 & -20.755 \\
\hline 0.0010 & 0.9590 & 1556 & 1.4926 & 4.3045 & 1.2991 & 1408.9 & 34.700 & -16.363 \\
\hline 0.0011 & 0.9580 & 1558 & 1.4928 & 4.2990 & 1.2982 & 1280.0 & 34.752 & -14.871 \\
\hline 0.0012 & 0.9570 & 1564 & 1.4971 & 4.2700 & 1.2938 & 1192.2 & 34.836 & -13.491 \\
\hline 0.0013 & 0.9578 & 1568 & 1.5018 & 4.2465 & 1.2903 & 1122.0 & 34.837 & -12.308 \\
\hline 0.0014 & 0.9585 & 1573 & 1.5083 & 4.2135 & 1.2852 & 1068.1 & 34.856 & -11.250 \\
\hline 0.0016 & 0.9590 & 1579 & 1.5144 & 4.1815 & 1.2804 & 955.9 & 34.884 & -9.697 \\
\hline 0.0018 & 0.9595 & 1584 & 1.5200 & 4.1530 & 1.2760 & 866.7 & 34.908 & -8.503 \\
\hline 0.0020 & 0.9606 & 1590 & 1.5278 & 4.1154 & 1.2702 & 801.7 & 34.919 & -7.507 \\
\hline
\end{tabular}

Table 4. The ultrasonic velocity and other acoustic parameters of the copper sesame soap-urea complex in a $20 \%$ methanol benzene mixture $\mathrm{CSeU}_{20}$.

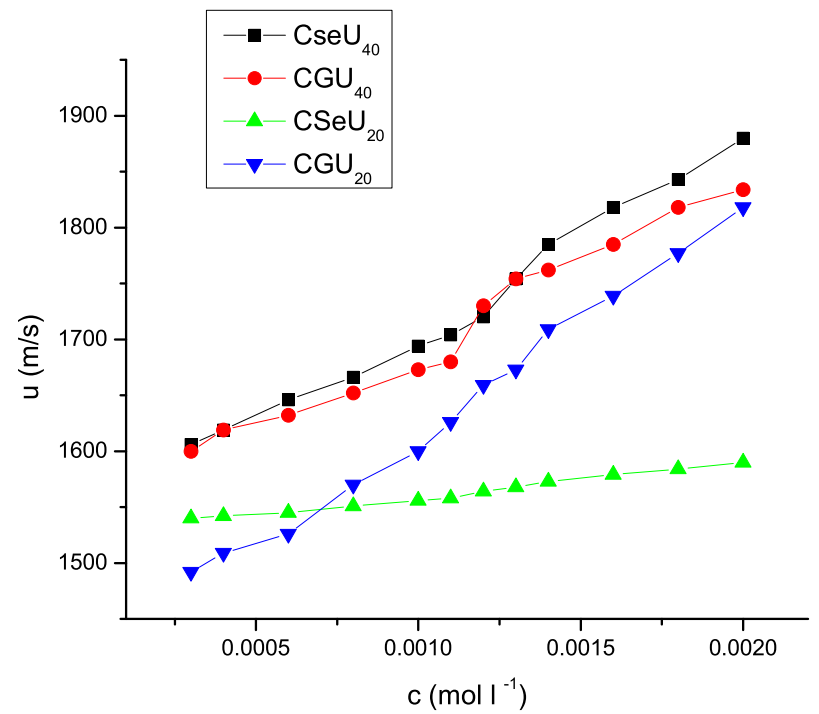

Fig. 1. Plots of $u$ versus $c$ of copper soap urea complex derived from groundnut and sesame oil in $20 \%$ and $40 \%$ methanol-benzene mixture.

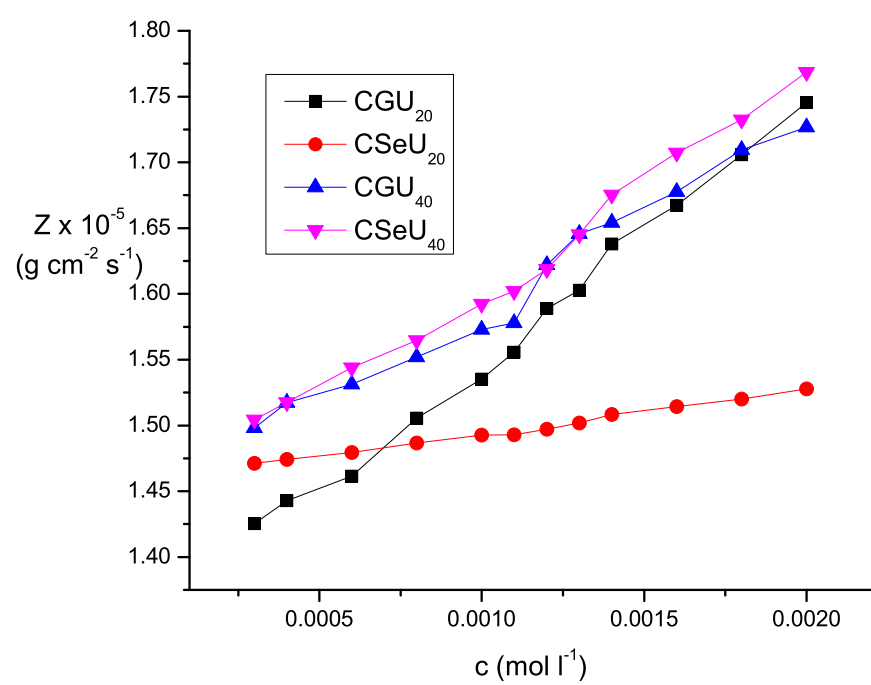

Fig. 2. Plots of $Z$ versus $c$ of copper soap urea complex derived from groundnut and sesame oil in $20 \%$ and $40 \%$ methanol-benzene mixture. 


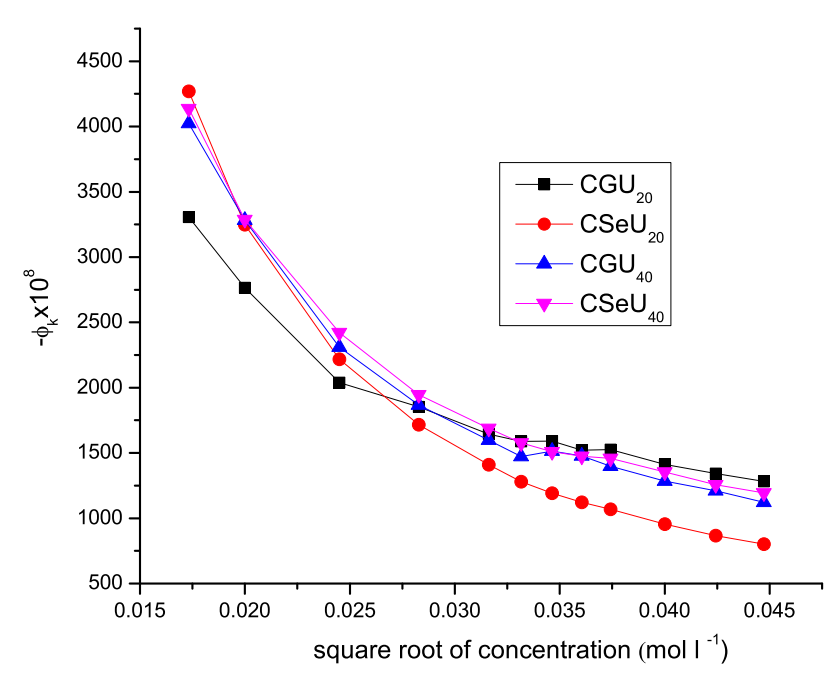

Fig. 3. Plots of $\phi_{k}$ versus $\sqrt{c}$ of copper soap urea complex derived from groundnut and sesame oil in $20 \%$ and $40 \%$ methanol-benzene mixture.

\section{Micellar Features}

The plots of $u, Z$, against the complex concentration $c$ are characterized by an intersection of two straight lines corresponding to the CMC of the complex (Figs.1-2). It is apparent from Table 7 that CMC is dependent on the composition of the solvent mixture. Like the copper soaps derived from various edible oils in a methanol-benzene mixture, the copper soap-urea complexes also obey equation (10) showing a linear variation of ultrasonic velocity with the complex concentration. The graphically determined values of $G$ are given in Table 8 . The values of the apparent molar compressibility $\phi_{k}$ increases with increasing the complex concentration. The values of $\phi_{k}$ are negative for all the urea complexes of copper soap. A literature survey reveals that a negative value of $\phi_{k}$ indicates electrostriction and a hydrophobic interaction. The negative values of $\phi_{k}$ are also attributed to the loss of structural compressibility of solute molecules. The plots of $\phi_{k}$ versus $\sqrt{c}$ are characterized by an intersection of two straight line corresponding to the CMC of the complex (Fig. 3). The $\phi_{k}$ data have been also analyzed in terms of Masson's equation. The parameters $\phi_{k}^{0}$ and $S_{k}$ have been evaluated both below and above CMC. The order of this parameter is as follows

$$
\phi_{k 1}^{0}<\phi_{k 2}^{0} \text { and } S_{k 1}>S_{k 2} \text {. }
$$

From this order it may be suggested that the solutesolvent interaction is more pronounced in a concentrated solution, i.e. above CMC as compared to below CMC. This observation is in good agreement with our apparent molar volume $v$ interpretations for complexes [17]. It is apparent from Table 7 that CMC value follows the order

$$
\mathrm{CSeU}>\mathrm{CGU} \text {. }
$$

The results are in agreement with the fact that there a decrease in the CMC value with the increase in the average molecular weight of the complex.

\section{B. Copper soap-urea complex derived from groundnut and sesame oils} in a $\mathbf{4 0} \%$ methanol-benzene mixture

\section{Acoustic Parameters}

At the very outset it may be mentioned that the acoustic parameters and related equations pertaining to the ultrasonic investigations of the above referred system are almost the same as have been enumerated for the $40 \%$ methanol-benzene mixture and are recorded in Tables $5-6$. The data clearly indicate that the value of $u, Z, \phi_{k}$, $R$ and $S_{n}$ increases whereas the value of $\beta$ and $L_{\mathrm{f}}$ decreases consistently with an increase in the complex concentration in varying compositions of methanol-benzene mixture [18].

\begin{tabular}{|c|c|c|c|c|c|c|c|c|}
\hline$c, \mathrm{~mol} \mathrm{l}^{-1}$ & $\rho, \mathrm{g} \mathrm{dm}^{-3}$ & $u, \mathrm{~m} \mathrm{~s}^{-1}$ & $Z \times 10^{-5}$ & $\beta \times 10^{11}$ & $L_{\mathrm{f}} \times 10^{10}$ & $-\phi_{k} \times 10^{8}$ & $R \times 10^{-2}$ & $S_{n} \times 10^{-3}$ \\
\hline 0.0003 & 0.9363 & 1600 & 1.4981 & 4.1720 & 1.2789 & 4022.6 & 29.452 & -48.673 \\
\hline 0.0004 & 0.9370 & 1619 & 1.5174 & 4.0694 & 1.2631 & 3282.4 & 29.551 & -34.547 \\
\hline 0.0006 & 0.9379 & 1632 & 1.5313 & 4.0000 & 1.2523 & 2311.3 & 29.608 & -22.131 \\
\hline 0.0008 & 0.9389 & 1652 & 1.5519 & 3.8984 & 1.2363 & 1866.5 & 29.703 & -15.623 \\
\hline 0.0010 & 0.9398 & 1673 & 1.5729 & 3.7987 & 1.2204 & 1597.3 & 29.802 & -11.737 \\
\hline 0.0011 & 0.9388 & 1680 & 1.5778 & 3.7710 & 1.2159 & 1471.7 & 29.878 & -10.512 \\
\hline 0.0012 & 0.9375 & 1730 & 1.6220 & 3.5636 & 1.1820 & 1515.3 & 30.213 & -8.385 \\
\hline 0.0013 & 0.9380 & 1754 & 1.6456 & 3.4638 & 1.1653 & 1477.4 & 30.340 & -7.160 \\
\hline 0.0014 & 0.9387 & 1762 & 1.6541 & 3.4309 & 1.1598 & 1398.0 & 30.364 & -6.462 \\
\hline 0.0016 & 0.9395 & 1785 & 1.6777 & 3.3379 & 1.1439 & 1283.7 & 30.478 & -5.213 \\
\hline 0.0018 & 0.9403 & 1818 & 1.7096 & 3.2171 & 1.1230 & 1210.3 & 30.640 & -4.126 \\
\hline 0.0020 & 0.9411 & 1834 & 1.7268 & 3.1561 & 1.1124 & 1121.6 & 30.712 & -3.480 \\
\hline
\end{tabular}

Table 5. The utrasonic velocity and other acoustic parameters of the copper groundnut soap-urea complex in a $40 \%$ methanol-benzene mixture $\mathrm{CGU}_{40}$. 


\begin{tabular}{|c|c|c|c|c|c|c|c|c|}
\hline$c, \mathrm{~mol} \mathrm{l}^{-1}$ & $\rho, \mathrm{g} \mathrm{dm}^{-3}$ & $u, \mathrm{~m} \mathrm{~s}^{-1}$ & $Z \times 10^{-5}$ & $\beta \times 10^{11}$ & $L_{\mathrm{f}} \times 10^{10}$ & $-\phi_{k} \times 10^{8}$ & $R \times 10^{-2}$ & $S_{n} \times 10^{-3}$ \\
\hline 0.0003 & 0.9364 & 1606 & 1.5043 & 4.1383 & 1.2737 & 4137.1 & 29.488 & -47.825 \\
\hline 0.0004 & 0.9372 & 1619 & 1.5177 & 4.0686 & 1.2629 & 3287.5 & 29.545 & -34.515 \\
\hline 0.0006 & 0.9380 & 1646 & 1.5440 & 3.9345 & 1.2420 & 2421.4 & 29.685 & -21.316 \\
\hline 0.0008 & 0.9388 & 1666 & 1.5647 & 3.8347 & 1.2261 & 1945.6 & 29.788 & -15.036 \\
\hline 0.0010 & 0.9395 & 1694 & 1.5924 & 3.7052 & 1.2052 & 1689.2 & 29.937 & -11.051 \\
\hline 0.0011 & 0.9400 & 1704 & 1.6020 & 3.6625 & 1.1983 & 1576.6 & 29.979 & -9.748 \\
\hline 0.0012 & 0.9410 & 1720 & 1.6189 & 3.5903 & 1.1864 & 1509.8 & 30.044 & -8.468 \\
\hline 0.0013 & 0.9377 & 1754 & 1.6451 & 3.4649 & 1.1655 & 1475.3 & 30.349 & -7.173 \\
\hline 0.0014 & 0.9382 & 1785 & 1.6754 & 3.3426 & 1.1447 & 1459.1 & 30.515 & -6.003 \\
\hline 0.0016 & 0.9390 & 1818 & 1.7073 & 3.2215 & 1.1238 & 1354.7 & 30.677 & -4.680 \\
\hline 0.0018 & 0.9398 & 1843 & 1.7324 & 3.1316 & 1.1080 & 1256.2 & 30.796 & -3.781 \\
\hline 0.0020 & 0.9405 & 1880 & 1.7687 & 3.0065 & 1.0857 & 1194.8 & 30.984 & -2.932 \\
\hline
\end{tabular}

Table 6. The ultrasonic velocity and other acoustic parameters of the copper sesame soap-urea complex in a $40 \%$ methanol benzene mixture $\mathrm{CSeU}_{40}$.

\section{Micellar Features}

The plots of acoustic parameters viz $u, Z$, against the complex concentration are characterized by an intersection of two straight lines (Figs. 1-2). Before CMC there is a slight curvature and after CMC the values of acoustic parameters are linear, which corresponds to the CMC of the complex. It is obvious from Table 7 that the CMC is dependent upon the composition of the solvent mixture. Like other copper soaps and their urea complexes, this complex also obeys equation $u=u_{0}+G_{c}$. The value of $G$ and $u_{0}$ were calculated from the $u$ versus $c$ plots and are shown in Table 8 . It is observed that the value of $u$ increases from the $20 \%$ to the $40 \%$ methanol-benzene mixture [19]. This obviously suggests that the behavior of the complex in benzene-dominated environment and methanol-dominated environment is quite different as they occupy different positions in palisade layers of soap and complex agglomerations. With regard to solvent mixture $u, Z$ and $\phi_{k}$ increase with the predominance of methanol in the $40 \%$ methanol-benzene solvent mixture whereas decrease with the predominance of benzene in the $20 \%$ methanol-benzene mixture [20]. The values of CMC of ultrasonic parameters are higher in the $40 \%$ methanol-benzene mixture as compared to the $20 \%$ methanol-benzene mixture. With regard to chain length of the soap segment of the complex molecules, the CMC follows the order:

\section{$\mathrm{CSeU}>\mathrm{CGU}$}

The plots of the apparent molar compressibility $\phi_{k}$ against the square root of the complex concentration $c$ are characterized by an intersection of two straight lines followed by convex curve (Fig. 3) and after CMC the value of $\phi_{k}$ increases near the CMC. The value of $\phi_{k}^{0}$ is evaluated from the intercept of the plots of $\phi_{k}$ versus $\sqrt{c}$ and values of $S_{k}$ are calculated from the slope of these plots and are recorded in Table 8 . The orders of these parameters are as follows:

$$
\phi_{k 1}^{0}<\phi_{k 2}^{0} \text { and } S_{k 1}>S_{k 2} \text {. }
$$

This suggests that solute solvent interaction is more prominent in a concentrated solution, i.e. above CMC as compared to below CMC. The value of $\phi_{k}$ is higher in the $40 \%$ methanol-benzene mixture as compared to the $20 \%$ methanol-benzene mixture. The values of $\phi_{k}$ is negative for all the copper soap-urea complexes. The negative $\phi_{k}$ values may be due to the loss of compressibility of the solvent due to strong electrostrictive forces in the vicinity of ions $[21,22]$.

\begin{tabular}{|c|c|c|c|c|}
\hline Plot & $\mathrm{CGU}_{20}$ & $\mathrm{CSeU}_{20}$ & $\mathrm{CGU}_{40}$ & $\mathrm{CSeU}_{40}$ \\
\hline$u$ vs $c$ & 0.0011 & 0.0012 & 0.0012 & 0.0013 \\
\hline$Z$ vs $c$ & 0.0011 & 0.0012 & 0.0012 & 0.0013 \\
\hline$\beta$ vs $c$ & 0.0011 & 0.00125 & 0.0012 & 0.00128 \\
\hline$L_{\mathrm{f}}$ vs $c$ & 0.0011 & 0.0012 & 0.0012 & 0.0013 \\
\hline$-\phi_{k}$ vs $\sqrt{c}$ & 0.0011 & 0.0012 & 0.0012 & 0.0013 \\
\hline
\end{tabular}

Table 7. CMC values of copper soap-urea complexes in the $20 \%$ and the $40 \%$ methanol-benzene mixture.

\begin{tabular}{|c|c|c|c|c|c|c|}
\hline Name of the Soap & $u, \mathrm{~m} \mathrm{~s}^{-1}$ & $G \times 10^{-5}$ & $\phi_{k 1} \times 10^{8}$ & $\phi_{k 2} \times 10^{8}$ & $S_{k 1} \times 10^{8}$ & $S_{k 2} \times 10^{8}$ \\
\hline $\mathrm{CGU}_{20}$ & 1425 & 0.3939 & -39.6 & -23.4 & 2.2460 & 0.5095 \\
\hline $\mathrm{CSeU}_{20}$ & 1532 & 0.4663 & -32.4 & -20.0 & 1.7320 & 0.7812 \\
\hline $\mathrm{CGU}_{40}$ & 1575 & 0.1944 & -35.0 & -24.8 & 1.7320 & 0.7812 \\
\hline $\mathrm{CGU}_{40}$ & 1565 & 0.2679 & -38.5 & -23.8 & 1.8040 & 0.6494 \\
\hline
\end{tabular}

Table 8. Various constants obtained from Masson's equation for copper soap-urea complexes in the $20 \%$ and the $40 \%$ methanol benzene mixture. 


\section{SUMMARY}

The nonlinear variation of the apparent molar compressibility $\phi_{k}$ and other acoustical parameters with the molar concentration of the copper soap-urea complex derived from groundnut and sesame oils with a $20 \%$ and a $40 \%$ methanol-benzene mixtures shows that the intermolecular interaction occurs in the constituent molecules. This provides significant information about the nature of the intermolecular forces existing in the mixture. The observed change in the behavior below and above the CMC is attributed to the fact that the aggregation of the solute molecules are different in the ternary mixtures of various concentrations, which suggests that the solute-solvent interaction is more prominent in a concentrated solution, i.e. above CMC as compared to below CMC. The value of $\phi_{k}$ is higher in a $40 \%$ methanol-benzene mixture as compared to a $20 \%$ methanol-benzene mixture suggesting that the behav- ior of solute in benzene dominated environment and methanol dominated environment is quite different as they occupy different positions in palisade layers of solute molecules, i.e. soap complex agglomerations. The negative $\phi_{k}$ values may be due to the loss of compressibility of the solvent due to strong electrostrictive forces in the vicinity of ions.

\section{AKNOWLEDGEMENTS}

The authors pay their sincere gratitude to UGC for Financial support, Principal, S. D. Govt. College, Beawar, S.P. C. Govt. College Ajmer Rajasthan (India) for providing necessary research facilities to accomplish this study. One of the authors, Dr. A. K. Sharma, is highly thankful to Dr. Gaurav Saxena (Assist. Prof.) Dept. of Physics GWECA Raj. for helping in the preparation of the manuscript in $\mathrm{AT}_{\mathrm{E}} \mathrm{X}$.
[1] S. Singh, I. Bahadur, J. Mol. Liq. 199, 518 (2014).

[2] S. Sharma, R. Sharma, A. K. Sharma, Asian J. Green Chem. 2, 129 (2017).

[3] P. Tank, R. Sharma, A. K. Sharma, Glob. J. Pharm. Pharm. Sci. 3, 1 (2017).

[4] S. Punitha, R. Uvarani, J. Saudi Chem. Soc. 18, 657 (2014).

[5] S. Sharma, R. Sharma, L. C. Heda, A. K. Sharma, J. Inst. Chemists (India) 89, 119 (2017).

[6] A. B. Naik, Ind. J. Pure Appl. Phys. 53, 27 (2015).

[7] P. Tank, A. K. Sharma, R. Sharma, J. Anal. Pharm. Res. 4, 1 (2017).

[8] S. Khan, R. Sharma, A. K. Sharma, Glob. J. Pharm. Pharm. Sci 3, 1 (2017).

[9] A. K. Sharma, S. Sharma, R. Sharma, Chron. Pharm. Sci. 1, 312 (2017).

[10] S. Rashmi, K. S. Arun, Biomed. J. Sci. Tech. Res. 1, 1 (2017).

[11] A. K. Sharma, N. Singh, M. Saxena, Synthesis, Spectroscopic and Biocidal Activity of Cu (II) Sesame Complex (LAP Lambert Academic Publishing, Saarbrücken, 2017).
[12] M. Saxena, R. Sharma, A. K. Sharma, Micellar Features of Cu (II) Surfactants Derived from Edible Oils (LAP Lambert Academic Publishing, Saarbrücken, 2017).

[13] R. Palani, S. Saravanan, R. Kumar, Rasayan J. Chem. 2, 622 (2009).

[14] S. Khan, R. Sharma, A. K. Sharma, Malaysian J. Chem. 19, 99 (2017).

[15] C. N. Mulligan, Colloid Interface Sci. 4, 372 (2009).

[16] A. K. Sharma, M. Saxena, R. Sharma, Tenside Surf. Det. 55 (2018) (accepted).

[17] K. Swain, P. Priyadarshani, Indian J. Pure Appl. Phys. 48, 539 (2010).

[18] A. K. Sharma, M. Saxena, R. Sharma, J. Pure Appl. Ultrason. 39, 92 (2017).

[19] K. Rajgopal, S. Chenthilnath, Indian J. Pure Appl. Phys. 48, 326 (2010).

[20] P. Tank, R. Sharma, A. K. Sharma, J. Acous. Soc. Ind. 44, 87 (2017).

[21] M. K. Praharaj, J. Chem. Pharma. Res. 4, 1910 (2012).

[22] P. B. Dabrase, R. A. Patil, B. M. Suryavanshi, J. Acoust. Soc. Ind. 40, 137 (2013).

\title{
АКУСТИЧНІ ДОСЛІДЖЕННЯ КОМПЛЕКСУ МИЛО-СЕЧОВИНА, ОТРИМАНОГО $З$ АРАХІСОВОЇ ТА КУНЖУТНОЇ ОЛІЙ
}

\author{
A. К. Шарма ${ }^{1}$, М. Саксена ${ }^{2}$, Р. Шарма ${ }^{1}$ \\ ${ }^{1}$ Кафедра хімї, Урядовий Коледж, Аджмер-305001, Раджастан, Індія \\ ${ }^{2}$ Кафедра хімї̈, Урядовий Коледж, Беавар-305901, Раджастан, Індія
}

\begin{abstract}
Виміряно ультразвукові швидкості та густини в потрійних сумішах, що містять комплекси милосечовина, отримані з арахісової та кунжутної олій в 20\%- та 40\%-суміші метанол-бензол. 3 цих значень визначено питомий акустичний імпеданс $Z$, адіабатичну стисливість $\beta$, міжмолекулярну довжину вільного пробігу $L_{\mathrm{f}}$, молярну стисливість $\phi_{k}$, молярну швидкість звуку $R$, число первинної сольватації $S_{n}$. Результати проаналізовано в термінах рівняння Массона та пояснено на основі міжмолекулярних взаємодій. Виявлено вплив полярності молекул розчинника та концентрації молекул розчинених речовин на різні акустичні параметри. Наші результати також дозволяють припустити, що поведінка мильного комплексу в середовищі, де переважає бензол, і навколишнього середовища, де переважає метанол, є різною, оскільки вони займають різні позиції в палісадних шарах агломерацій мильних комплексів.
\end{abstract}

